\title{
Reaksi Investor atas Laporan Keberlanjutan: Keberagaman Gender Direksi dan Independensi Direksi sebagai Variabel Moderasi
}

\section{Redilla Wisman 1 \\ Fakultas Ekonomi dan Bisnis Universitas Pelita Harapan, Indonesia}

\author{
Wijaya Triwacananingrum ${ }^{2}$ \\ Fakultas Ekonomi dan Bisnis \\ Universitas Pelita Harapan, Indonesia
}

\begin{abstract}
ABSTRAK
Pendekatan Triple Bottom Line menjadikan perusahaan mulai mempertimbangkanlaporannon-finansial-nya sebagai nilai tambah bagi pemangku kepentingannya. Penelitian menggunakan judgement sampling dalam pengambilan sampel. Jumlah sampel sebanyak 132 data dari perusahaan sektor ind ustri dan sumber daya mineral pada SGX tahun 2018 - 2020. Teknik analisa data dalam penelitian ini menggunakan regresi linier berganda. Reaksi investor diukur berdasarkan cumulative abnormal return dengan rentang peristiwa sebanyak tujuh hari. Laporan keberlanjutan diukur dengan mengacu pada indeks GRI standar. Hasil penelitian menyatakan kualitas laporan keberlanjutan tidak berpengaruh signifikan terhadap reaksi investor, keberagaman gender direksi tidak signifikan dalam memperkuat hubungan laporan keberlanjutan dengan reaksi investor, dan independensi direksi berperan signifikan dalam memperkuat hubungan kualitas laporan keberlanjutan dengan reaksi investor.
\end{abstract}

Surel : redillaw98@gmail.com

Kata Kunci: Reaksi Investor; Laporan Keberlanjutan; Keberagaman Gender Direksi; Independensi Direksi.

Investors' Reaction on Sustainability Report: Board Gender Diversity and Board Independence as Moderation Variables

\begin{abstract}
The Triple Bottom Line approach makes the company start to consider its non-financial reports as an addedvalue for its stakeholders. Thestudy used judgment sampling in sampling. The number of samples is 132 data from industrial sector companies and mineral resources in the 2018-2020 SGX. The data analysis technique in this study uses multiple linear regression. Investor reactions are measured based on cumulative abnormal returns with an event span of seven days. Sustainability reports are measured by reference to the standard GRI index. The results show that the quality of sustainability reports has no significant effect on investor reactions, the gender diversity of directors is not significant in strengthening the relationship between sustainability reports and investor reactions, and the independence of directors plays a significant role in strengthening the relationship between the quality of sustainability reports and investor reactions.
\end{abstract}

Keywords: $\quad$ Investors' Reaction; Sutainability Report; Board Gender Diversity; Board Independence.

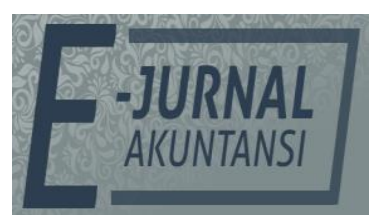

e-ISSN 2302-8556

Vol. 31 No. 12

Denpasar, Desember 2021

Hal. 2949-2963

$10.24843 / E$

DOI:

PENGUTIPAN:

Wisman, R. \&

Triwacaningrum, W. (2021).

Reaksi Investor atas Laporan

Keberlanjutan: Keberagaman

Gender Direksi dan

Independensi Direksi sebagai Variabel Moderasi.

E-Jurnal Akuntansi, 31(12), 2949-2963

RIWAYAT ARTIKEL:

Artikel Masuk: 7 September 2021 Artikel Diterima: 9 Desember 2021

Artikel dapat diakses: https:/ /ojs.unud.ac.id/index.php/Akuntansi/index 


\section{PENDAHULUAN}

Dewasa ini, perusahaan tidak hanya dipertimbangkan dalam aspek finansialnya saja. Dalam buku Making Sustainability Work, Epstein \& Buhovac (2014: 5) mengatakan, "Corporations have become more sensitive to social, environmental, and economic issues and stakeholder concerns. ... The result is that managers must make significant changes to more effectively manage their social, economic, and environmental impacts.". Pernyataan tersebut memunculkan sebuah istilah yang dikenal dengan dengan 'Triple Bottom Line' atau 3P (Profit, People, dan Planet), menjadikan para pemangku kepentingan membutuhkan adanya pengungkapan informasi nonfinansial perusahaan. Adapun tujuannya untuk melihat pertumbuhan keberlanjutan perusahaan. Perusahaan yang menyajikan laporan non-finansial akan menjadi keunggulan kompetitif bagi perusahaan tersebut, hal ini karena laporan non-finansial dapat menambah informasi dalam eknik profit dan risiko dimasa mendatang (Epstein \& Buhovac, 2014). Aspek-aspek non-finansial dapat dijadikan informasi sehubungan dengan bagaimana dampak dari 'exhale' perusahaan akibat dari kegiatan usahanya. Setelah mengetahui dampak tersebut, perusahaan menentukan dan melakukan upaya keberlanjutan dalam mengelola sumber daya yang digunakan agar tidak ada yang terancam ketersediannya dan atau dirugikan, sebagaimana ini menjadi sebuah bentuk pertanggungjawabannya kepada pemangku kepentingan terkait nilai sosial dan lingkungan. Perusahaan dapat mengunakan laporan keberlanjutan dalam mengungkapkan aspek nonfinansial-nya. Dimana didalamnya berisikan informasi sehubungan dengan aspek ekonomi, tata eknik, sosial, etika dan lingkungan (EGSEE) (Rezaee et al., 2019).

Dalam penelitian ini, manfaat dari adanya laporan tersebut secara spesifik akan di pandang melalui perspektif investor. Pemilihan ini didukung oleh pernyataan yang disampaikan dalam artikel Mckinsey \& Company yaitu, laporan non-finansial membantu menstimulasi pertumbuhan investasi yang berkelanjutan, oleh karena itu, para investor mulai mempertanyakan praktik pelaporan keberlanjutan dan mulai menyerukan kepada eksekutif serta dewan perusahaan untuk memahami perubahan ini. Para investor mendukung apabila laporan keberlanjutan dipelakukan sama seperti laporan keuangan, yang mana artinya memiliki konsistensi keseragaman pelaporan perusahaan satu dengan lainnya, hal ini memudahkan pengguna, khususnya investor menggunakan informasi yang disajikan untuk penentuan keputusan investasinya (Bernow et al., 2019). Reaksi dari investor atas adanya informasi tersebut dapat dihitung menggunakan cumulative abnormal return (CAR) dalam rentang waktu peristiwa tertentu. Nantinya, hasil ini akan menunjukkan dampak dari peristiwa yang diobservasi. Adapun dalam penelitian ini peristiwa yang dimaksud ialah penerbitan laporan keberlanjutan oleh perusahaan. Hal ini juga erat kaitannya dengan Efficient Market Hypothesis (EMH). Berdasarkan EMH, transaksi terkait saham pada pasar akan mengacu kepada nilai wajarnya. Oleh sebab itu, harga saham tidak bisa hanya mengandalkan informasi dan faktor yang konsisten (Bodie et al., 2018). Tetapi, masih terdapatnya faktor-faktor pada pasar yang mempengaruhi nilai tersebut seperti, kondisi ekonomi makro, fluktuasi nilai tukar rupiah, kebijakan pemerintah, fundamental perusahaan, aksi korporasi, serta proyeksi kinerja perusahaan masa depan (OJK, 2019). Pasar yang efisien dapat dipengaruhi salah 
satunya oleh sinyal yang ditimbulkan akibat keandalan informasi perusahaan, baik finansial maupun non-finansial (Berk et al., 2015).

Efisiensi pasar bergantung pada keandalan informasi finansial dan nonfinansial, yang memungkinkan pasar untuk bertindak sebagai mekanisme sinyal untuk alokasi modal yang tepat dan potensi pemenuhan tanggung jawab dan pencapaian kinerja EGSEE (Ng \& Rezaee, 2020). Antusiasme investor terhadap suatu perusahaan akan berpengaruh dalam sumber pendanaan perusahaan, dengan kata lain dapat mempengaruhi kemauan investor untuk melakukan investasi. Beberapa kegunaan laporan keberlanjutan berdasarkan perspektif investor ialah, identifikasi serta asesmen risiko dan potensi pengembalian, evaluasi kualitas tata eknik, sebagai sarana komunikasi perusahaan dengan investor, pertimbangan dalam portofolio investasi, dan evaluasi manajer ekni (Brockett \& Rezaee, 2012).

Salah satu sarana perusahaan mengkomunikasikan informasi non-finansialnya yakni menggunakan laporan keberlanjutan. Laporan keberlanjutan adalah pengungkapan informasi perusahaan yang berperan sebagai sarana untuk menyampaikan informasi terkait dengan lingkungan, sosial dan tata eknik didalam kegiatan operasionalnya, baik tujuan maupun perkembangannya. Laporan keberlanjutan membantu perusahaan untuk mempertimbangkan dampak perusahaan secara luas sehubungan dengan permasalahan keberlanjutan, serta perusahaan akan lebih transparan tentang kesempatan dan risiko yang mereka hadapi (GSSB, 2016). Tiga prinsip utama keberlanjutan bisnis adalah penciptaan nilai, peningkatan kinerja, dan jaminan akuntabilitas. Pelaporan keberlanjutan memungkinkan perusahaan untuk mengungkapkan strategi, komitmen, dan kinerja dalam aspek EGSEE, guna memastikan pencapaian target keuangan jangka panjang sejalan dengan upaya mitigasi dampak eknik i sosial dan lingkungan (Brockett \& Rezaee, 2012).

$\mathrm{H}_{1}$ : Kualitas Laporan Keberlanjutan Berpengaruh Signifikan Positif Terhadap Reaksi Investor.

Pengembangan hipotesis diatas turut didasari oleh beberapa teori yakni, teori pemangku kepentingan, teori legitimasi, teori ekonomi sosial, dan teori sinyal. Pada teori pemangku kepentingan Berle \& Mean (1933) berargumen bahwa perusahaan tidak hanya mempertanggungjawabkan segala kegiatan dan keputusannya kepada pemegang saham, perusahaan turut bertanggung jawab pada seluruh pihak yang mempengaruhi atau terpengaruhi dari kegiatan perusahaan. Selain itu, Freeman mengatakan bahwa inti dari teori ini ialah perusahaan memiliki kewajiban untuk menciptakan nilai bagi seluruh pemangku kepentingan, yang mana dalam menjalankan kegiatannya perusahaan juga harus memperhatikan moral serta nilai-nilai yang berlaku (Parmar et al., 2010). Menurut perspektif legitimasi, organisasi mengeluarkan laporan sosial guna mengurangi biaya eksternal atau mengurangi tekanan yang diperoleh dari pemangku kepentingan atau regulator eksternal (Tate et al., 2010). Perusahaan menyajikan laporan keberlanjutan sebagai kontrak secaraimplisit yang menunjukan tanggung jawabnya kepada perusahaannya sendiri dan kepada sosial. Perusahaan yang mengeluarkan laporan untuk mendukung strategi bisnis lebih cenderung untuk meningkatkan pengungkapan mereka (Gray et al., 1995). Berikutnya, teori ekonomi sosial mempertegas manfaat dari laporan keberlanjutan, perusahaan 
akan lebih baik ketika tidak hanya terfokus pada nilai ekonomi saja tetapi juga memperhatikan nilai sosialnya. Beberapa permasalahan dari legitimasi bisa terselesaikan dengan teori ini, ketika terdapat perbedaan antara nilai-nilai komunitas dan nilai-nilai perusahaan berserta dengan dampaknya (Deegan, 2002; Patten, 1992). Terakhir, berdasarkan teori sinyal dengan adanya pengungkapan laporan keberlanjutan akan mengantarkan sinyal kepada pasar atau investor. Perusahaan dengan eknik ic kinerja keberlanjutan yang lebih baik akan cenderung mengkomunikasikan hasil dan dampaknya lebih sering dibandingkan perusahaan dengan tingkat kinerja yang lebih rendah (Ching \& Gerab, 2017) dan (Thorne et al., 2014).

Teori keagenan juga digunakan sebagai dasar dalam pengembangan hipotesis penelitian ini. Menurut Jensen \& Meckling (1976), teori keagenan bermaksud untuk mendeskripsikan secara garis besar atas adanya kontrak secara implisit antara principal (pemegang saham) dan agen (manajemen), dimana agen diamanatkan oleh principal untuk bertindak agar mendapatkan keuntungan yang maksimal. Direksi yang hanya mementingkan untuk maksimalisasi pertumbuhan perusahaan saja tanpa memperhatikan pendapatan akan memunculkan permasalahan keagenan, hal ini dalam konteks pengambilan keputusan bisnisnya. (Kaplan, 2019) dan (Nyatichi, 2017). Dewan direksi merupakan pihak yang bertanggung jawab untuk segala informasi perusahaan yang disampaikan. Dewan direksi ditunjuk oleh pemegang saham untuk melakukan pengawasan terhadap fungsi manajerial. Secara teoritis, keberadaan dewan direksi menyelesaikan permasalahan agensi yang berkaitan dengan pemisahan antara eknik pemilik perusahaan dengan eknik pengambilan keputusan (Rezaee, 2009). Oleh karena itu, Komposisi dari dewan direksi sangat penting untuk penciptaan nilai jangka panjang, dan transparasi. Investor ingin mengetahui bahwa dewan memiliki proses untuk meninjau dan mengembangkan komposisi dewan sehubungan dengan kebutuhan yang muncul (Stuart, 2017).

Beberapa temuan penelitian terdahulu yang cukup terkait dengan pengembangan hipotesis sehubungan topik pembahasan ini antara lain: hubungan positif yang signifikan antara komposisi dewan dan kinerja keuangan (Nyatichi, 2017). Dampak timbal balik dari komposisi dewan dan praktik Corporate Social Responsibility (CSR) pada pengembalian organisasi menunjukkan independensi dewan dan keberagaman gender berefek eknik i (Karim et al., 2020); Dewan dengan partisipasi perempuan yang lebih tinggi meningkatkan legitimasi pelaporan CSR. Independensi dan keberagaman gender dewan memfasilitasi pengarahan eknik i dari sumber daya perusahaan yang langka

eknik proyek sosial yang memaksimalkan nilai dan pelaporan selanjutnya tentang hal ini (Jizi, 2017). CSR tidak terdampak oleh komposisi eknik dalam dewan direksi (Hasanah \& Rudyanto, 2020) dan Perbedaan gender dan pengungkapan laporan keberlanjutan secaralangsung berpengaruh terhadap nilai perusahaan (Novita \& Saputra, 2020).

Komposisi dewan direksi disini diwakilkan dengan keberagaman gender direksi dan independensi direksi. Keragaman gender merepresentasikan komposisi anggota dewan berjenis kelamin eknik. Hal ini akan mengarah pada basis pengetahuan, kreatifitas, inovasi, serta ide dalam pemecahan masalah dan pengambilan keputusan yang lebih luas (Nyatichi, 2017). 
$\mathrm{H}_{2}$ : Keberagaman Gender Dewan Direksi Dapat Memperkuat Hubungan Kualitas Laporan Keberlanjutan Dengan Reaksi Investor.

Kemudian, independensi dewan direksi, hal ini menjadi esensial dalam efektivitas dewan direksi ketika merepresentasikan dan menjaga kepentingan pemegang saham. Independen disini berarti pihak tersebut tidak memiliki hubungan apapun selain kedewanannya, yang mana dapat mempengaruhi objektivitas dan loyalitasnya (Nyatichi, 2017) dan (Rezaee, 2009).

$\mathrm{H}_{3}$ : Independensi Dewan Direksi Dapat Memperkuat Hubungan Kualitas

Laporan Keberlanjutan Dengan Reaksi Investor.

Berdasarkan gambar dibawah ini dapat dilihat keterkaitan landasan teori dan konsep dasar yang digunakan dalam pengembangan hipotesis-hipotesis pada penelitian ini.

\begin{tabular}{|c|c|c|c|}
\hline $\begin{array}{l}\text { Laporan Keberlanjutan(KSR) } \\
\text { Teori Ekonomi Sosial } \\
\text { Teori Legitimasi }\end{array}$ & $\bar{\tau}^{\mathrm{H}} 1$ & & $\begin{array}{l}\text { Reaksi Investor (CAR) } \\
\text { Teori Pemangku Kepentingan } \\
\text { Teori Sinyal }\end{array}$ \\
\hline & $\mathrm{H} 2$ & $\mathrm{H} 3$ & \\
\hline $\begin{array}{l}\text { Keberagaman Gender Direksi (BD) } \\
\text { Teori Keagenan }\end{array}$ & & & $\begin{array}{l}\text { Independensi Direksi (BD) } \\
\text { Teori Keagenan }\end{array}$ \\
\hline
\end{tabular}

Sumber: Data Penelitian, 2021

\section{Gambar 1. Kerangka Pemikiran}

Perusahaan pada sektor eknik i dan sumber daya mineral yang tercatat pada bursa efek Singapura (SGX) akan menjadi objek penelitian kali ini. Pemilihan objek ini berdasarkan ketersediaan data serta fakta-fakta pendukung. Salah satunya adalah adanya peraturan yang bersifat wajib untuk menerbitkan laporan keberlanjutan bagi perusahaan yang tercatat dalam SGX sesuai dengan SGX Rulebooks bab 7 Practice Note 7.6 (SGX, 2016). Sektor eknik i dipilih dalam penelitian ini dikarenakan Sektor eknik i adalah sektor yang mengkonsumsi energi terbesar di Singapura, sehingga pengelolaan energi yang lebih baik dan berkelanjutan berpotensi menghemat energi secara signifikan. Manajemen energi yang lebih baik mengarah pada efisiensi energi, yang akan membantu perusahaan mengurangi risiko 'bottom line'. Sedangkan, Sektor sumber daya mineral dipilih berdasarkan seluruh kegiatan bisnisnya bergantung dan menggunakan sumber yang berada lingkungan. Sumber daya mineral merupakan konsentrasi atau kemunculan bahan yang memiliki kepentingan ekonomis eknik ic. Bahan ini berada pada kerak bumi dalam bentuk, kualitas, dan kuantitas yang memiliki prospek yang masuk akal untuk tujuan akhir ekstraksi keuntungan ekonomi (SGX, 2017).

Penelitian ini berfokuskan pada standar penyajian laporan keberlanjutan yang diterbitkan oleh Global Reporting Initiative (GRI) pada tahun 2016 yakni disebut dengan GRI standar. Sebelum GRI standar, perusahaan menggunakan standar yang dikenal dengan G4. Sehingga, tahun 2017 merupakan masa transisi perusahaan dalam menyajikan laporan keberlanjutannya menggunakan G4 menjadi GRI standar. Akan tetapi, secara mayoritas perusahaan mulai beralih ke GRI standar sejak 2018. 
Rumusan masalah dalam penelitian ini yakni, apakah laporan keberlanjutan mempengaruhi reaksi investor?, apakah keberagaman gender direksi dapat memperkuat hubungan laporan keberlanjutan dengan reaksi investor?, dan apakah independensi direksi dapat memperkuat hubungan laporan keberlanjutan dengan reaksi investor?. Adapun tujuannya ialah untuk melihat pengaruh dari laporan keberlanjutan terhadap reaksi investor, serta untuk menentukan keberagaman gender direksi dan independensi direksi dapat memperkuat hubungan laporan keberlanjutan dengan reaksi investor.

\section{METODE PENELITIAN}

Populasi merujuk pada keseluruhan dalam kelompok suatu konteks, manusia atau fenomena yang menarik bagi peneliti untuk dilakukan investigasi atau penelitian, yang kemudian akan ditarik suatu dugaan atau kesimpulan tertentu (Sekaran \& Bougie, 2016). Berdasarkan pengertian populasi tersebut, maka populasi dalam penelitian ini adalah seluruh perusahaan pada sektor eknik i dan sumber daya mineral yang tercatat dalam bursa efek Singapura (SGX) sebanyak 251 perusahaan dari total seluruh perusahaan tercatat adalah 661 . Selanjutnya, Metode pengambilan sampel dalam penelitian ini mengunakan nonprobability sampling dengan pendekatan purposive sampling yang berkategori judgement sampling.

\section{Tabel 1. Pemilihan Sampel}

\begin{tabular}{lc}
\hline \multicolumn{1}{c}{ Keterangan } & Hasil \\
\hline Seluruh perusahaan dalamSGX & 661 \\
Perusahaan selain sektor industridan sumber daya mineral & $(410)$ \\
Perusahaan sektor industri dan sumber daya mineral & 251 \\
Tidak memenuhi kriteria pemilihan sampel & $(205)$ \\
Total perusahaan yang dapat dijadikan sampel & 46 \\
Total sampel untuk tahun 2018-2020 & 138 \\
Pengurangannilai ekstrem & $(6)$ \\
Total sample observasi & 132 \\
\hline
\end{tabular}

Sumber: Data Penelitian, 2021

Karakteristik dalam penentuan sampel penelitian ini adalah sebagai berikut: Seluruh perusahaan pada sektor eknik idansumber daya mineralyang tercatat dalam bursa efek Singapura pada tahun 2018 sampai dengan 2020, Perusahaan menerbitkan laporan keberlanjutan yang berdiri sendiri pada situs bursa efek Singapura, dan Pedoman penyajian laporan keberlanjutan mengunakan GRI standar, untuk masa periode laporan 1 Januari sampai dengan 31 Desember. Setelah ditentukan karakteristik data, kemudian dari 251 perusahaan hanya menyisakan 46 perusahaan. Maka, untuk tahun 2018 - 2020 diperoleh 138 data perusahaan. Adapun tahap pemilihan sampel dapat dilihat pada tabel 1. Akan tetapi, karena dalam hasil eknik ic deskriptif terindikasi adanya outliers atau nilai ekstrem, sehingga data dihilangkan sebanyak enam data yang menjadi 132 data observasi.

Data penelitian yang digunakan merupakan data sekunder. Data sekunder adalah data yang telah dikumpulkan oleh pihak lain untuk tujuan lain selain dari tujuan penelitian ini (Sekaran \& Bougie, 2016). Struktur data dalam penelitian ini merupakan cross sectional. Artinya, data terdiri dari banyak perusahaan dalam 
sedikit tahun yang diperlakukan secara terpisah (Bynner, 2015). Sumber data penelitian ini adalah S\&P, situs resmi SGX (https:/ / www.sgx.com), dan Yahoo Finance. Teknik pengumpulan data yang akan digunakan untuk data sekunder adalah studi kepustakaan. Data yang digunakan pada eknik ini berdasarkan telaah literasi, catatan, laporan dan sebagainya yang berkaitan dengan topik penelitian yang sedang dijalankan (Nazir, 2013).

Model empiris penelitian kali ini adalah sebagai berikut:

$\mathrm{CAR}=\mathrm{a}+\beta_{1} \mathrm{KSR}+\beta_{2} \mathrm{BD}+\beta_{3} \mathrm{BI}+\beta_{4} \mathrm{KSR} \_\mathrm{BD}+\beta_{5} \mathrm{KSR} \_\mathrm{BI}+\beta_{6} \operatorname{Size}+\beta_{7} \mathrm{NP}+\varepsilon$.

Keterangan :

\begin{tabular}{|c|c|}
\hline CAR & $=$ Reaksi Investor \\
\hline KSR & $=$ Laporan Keberlanjutan \\
\hline BD & = Keberagaman Gender Direksi \\
\hline BI & = Independensi Direksi \\
\hline KSR_BD & $=$ Pemoderasi Keberagaman Gender Direksi \\
\hline KSR_BI & $=$ Pemoderasi Independensi Direksi \\
\hline Size & $=$ Ukuran Perusahaan \\
\hline NP & = Nilai Perusahaan \\
\hline a & $=$ Konstanta \\
\hline & $=$ Error \\
\hline
\end{tabular}

Variabel dependen dalam penelitian ini adalah reaksi investor yang dapat dihitung menggunakan Cumulative Abnormal Return (CAR) dalam rentang waktu tertentu (Benninga \& Voetmann, 2014; Bodie et al., 2018). Dikarenakan tidak adanya aturan pasti tentang lamanya estimasi studi peristiwa dan jendela peristiwa. Setiap peneliti memiliki pilihan diskresioner saat memutuskan tentang parameter ini (Event Study, 2020). Adapun rentang waktu kali ini berawal pada tiga hari sebelum tanggal penerbitan laporan keberlanjutan sampai dengan tiga hari setelah tanggal penerbitan laporan keberlanjutan, sehingga totalnya menjadi sebanyak tujuh hari. Dalam formula perhitungan, actual return merujuk pada harga historis pasar saham masing-masing perusahaan. Sedangkan untuk expected return merujuk pada indeks harga historis pada SGX yaitu FTSE Strait Times Index. Seluruh harga saham yang digunakan merupakan harga penutupan. Formula perhitungan seperti yang tercantum sebagai berikut.

CAR $=\sum_{n=1}^{n}$ Actual return - Expected return.

Actual return $=\sum_{n=1}^{n} \frac{\text { stock price }_{n}-\text { stock price }_{n-1}}{\text { stock price }_{n-1}}$

Expected return $=\sum_{n=1}^{n} \frac{F T S E S T I_{n}-F T S E S T I_{n-1}}{F T S E S T I_{n-1}}$

Laporan keberlanjutan merupakan variabel indepeden, yang pengukurannya didasari dengan indeks pelaporan dengan standar pelaporan GRI Standar. Perhitungan variabel ini yaitu dengan membagi poin indeks perusahaan dengan total poin GRI standar sebanyak 235 poin (Tan et al., 2016). Selanjutnya, keberagaman gender direksi dan independensi direksi berperan sebagai variabel moderasi. Adapun, perhitungan kedua variabel ini memiliki formula yang tidak jauh berbeda yaitu dengan membagi jumlah anggota dewan ber-gender wanita atau berstatus sebagai direksi independen dengan total anggota dewan masingmasing perusahaan (Jizi, 2017). Nantinya, hasil dari ketiga variabel ini akan berada 
pada bilangan 0 sampai dengan 1 . Penelitian ini juga turut menggunakan ukuran perusahaan dan nilai perusahaan sebagai variabel kontrol. Ukuran perusahaan dihitung dengan logaritma natural (Ln) dari total aset dan nilai perusahaan dihitung menggunakan tobin's $Q$ yaitu membagi kapitalisasi pasar dengan total aset masing-masing perusahaan (Noronha et al., 2018) dan (Tan et al., 2016).

Penelitian ini termasuk penelitian kuantitatif dengan pendekatan hypothetico deductive, artinya, penelitian ini bertujuan untuk membuktikan suatu teori melalui sampel yang digunakan. Dimana, pendekatannya dari umum menuju ke khusus (deduktif) (Sekaran \& Bougie, 2016). Untuk menganalisa dibutuhkan pengolahan data yang dapat dibantu dengan menggunakan perangkat lunak statistik yakni IBM SPSS. Selanjutnya, dikarenakan variabel dependen yang dipilih merupakan continuous variable, maka analisis data berdasarkan statistik deskriptif dan pendekatan regresi Ordinary Least Square (OLS) atau linier berganda berserta dengan uji asumsi klasik (Ghozali, 2018). Peneliti menggunakan statistikdeskriptif untuk melihat bagaimana karakter daripada data yang digunakan. Karakter data digambarkan melalui nilai rerata, nilai maksimal, nilai minimal, serta standar deviasi dari masing-masing variabel yang digunakan dalam model penelitian (Sekaran \& Bougie, 2016).

Pengujian asumsi klasik digunakan untuk menentukan apakah asumsi dari regresi OLS sudah terlaksana. Adapun asumsi yang dimaksud berhubungan dengan Best Linear Unbiased Estimator (BLUE). Implikasi terhadap data dari estimator atau penduga tersebut ialah efisiensi, menghindari bias, konsisten, serta memiliki pendistribusian normal. Asumsi klasik terdapat empat pengujian yaitu, multikolinearitas, normalitas, heteroskedastisitas dan autokorelasi. Menurut Ghozali (2018), dalam menguji normalitas dapat menggunakan metode statistik yang dilihat melalui hasil asymptotic significance pada One Sample KolmogorovSmirnov, dengan kriterianya yaitu apabila hasil lebih besar dari 0,05 maka data terdistribusi normal. Sebaliknya jika hasil kurang dari 0,05 maka data tidak terdistribusi normal yang berdampak pada penurunan hasil statistiknya. Kemudian untuk uji multikolinearitas diindikasi mengunakan nilai collinear statistic, tepatnya, nilai VIF dan tolerance. Adapun kriterianya dikatakan terdapat multikolinearitas apabila nilai VIF lebih besar dari 10 dan nilai tolerance lebih kecil dari 0,1. Asumsi klasik multikolinearitas dikatakan terpenuhi ketika tidak terdapat multikolinearitas didalamnya Ghozali (2018). Berikutnya, heteroskedastisitas yang diuji menggunakan scatterplot dengan kriteria dikatakan tidak terdapat permasalahan ketika titik plot menyebar pada atas dan bawah garis horizontal 0 serta tidak adanya pola yang terbentuk. Pengujian terakhir yaitu uji autokorelasi dalam penelitian ini tidak digunakan, karena uji tersebut hanya dibutuhkan bagi data berjenis time series (Ghozali, 2018) dan (Mulyono, 2019).

Regresi OLS dapat digunakan untuk menguji keberartian model dan menguji hipotesis. Dimana, untuk menguji keberartian model mengacu pada uji koefisien determinasi $\left(R^{2}\right)$ dan uji simultan F. Uji koefisien determinasi atau uji $R^{2}$ memperlihatkan seberapa besar variabel-variabel independen yang digunakan dalam suatu penelitian dapat mempengaruhi variabel dependen-nya. Sedangkan, pengujian kedua ialah uji F. Uji ini akan menggambarkan seluruh variabel independen dalam model penelitian secara simultan berpengaruh terhadap variabel dependen (Sekaran \& Bougie, 2016) dan (Setiawan, 2015). Terakhir, uji 
hipotesis yang menggunakan uji parsial atau uji t. Pengujian ini melihat bagaimana masing-masing variabel independen secara individual mempengaruhi variabel dependen dengan menggunakan perhitungan Anova (Ghozali, 2018). Tingkat signifikansi yang digunakan adalah 0,05. Sehingga, dasar dalam menafsirkan hasil uji parsial $t$ antara lain: Sig. $<0,05$ dan $t$ positif, artinya hipotesis signifikan dan berarah positif; Sig. $<0,05$ dan $\mathrm{t}$ negatif, artinya hipotesis signifikan dan berarah negatif; dan Sig. > 0,05, artinya hipotesis ditolak.

\section{HASIL DAN PEMBAHASAN}

Hasil penelitian ini berdasarkan 132 sampel yang didapatkan dari penentuan kriteria serta pembuangan outliers terhadap perusahaan sektor industri dan sumber daya mineral dalam bursa efek Singapur.

Tabel 2. Hasil Uji Statistik Deskriptif

\begin{tabular}{lccccc}
\hline & $\mathrm{N}$ & Min. & Maks. & Rata-Rata & Std. Dev. \\
\hline CAR & 132 & $-0,415$ & 2,042 & 0,074 & 0,286 \\
KSR & 132 & 0,145 & 0,664 & 0,271 & 0,108 \\
BD & 132 & 0,000 & 0,600 & 0,118 & 0,131 \\
BI & 132 & 0,000 & 0,818 & 0,526 & 0,115 \\
KSR_BD & 132 & 0,000 & 0,255 & 0,035 & 0,047 \\
KSR_BI & 132 & 0,000 & 0,543 & 0,145 & 0,081 \\
SIZE & 132 & 15,472 & 24,168 & 18,876 & 1,467 \\
NP & 132 & 0,0416 & 308,949 & 2,841 & 26,867 \\
Valid N & 132 & & & & \\
\hline
\end{tabular}

Sumber: Data Penelitian, 2021.

Gambaran data penelitian ini untuk variabel CAR ialah -0,415; 2,042; dan 0,074 secara berurutan untuk retur minimum, maksimal dan rerata. Kemudian untuk KSR, paling sedikit perusahaan mengungkapkan $14,5 \%$ atau 34 dari 235; paling banyak senilai $66,4 \%$ atau 156 poin dari 235; dan rata-rata pengungkapan sebesar 27,1\% atau 64 dari 235 poin. Selanjutnya untuk BD dan BI nilai minimum ialah tidak terdapat anggota dewan berstatus wanitaatau independen. Sedangkan untuk proporsi tertinggi secara berurutan ialah $60 \%$ dan $82 \%$ dari total anggota dewan. Terakhir untuk rerata adalah $11,8 \%$ dari total untuk BD dan 52,6\% dari total dewan untuk BI.

Rangkaian pengujian selanjutnya adalah uji asumsi klasik. Berdasarkan tabel 3 uji normalitas mengunakan One Sample Kolmogorov-Smirnov hasil asymptotic significance menunjukan nilai dibawah 0,05 yaitu 0,000. Dimana artinya residual data belum terdistribusi secara normal.

Pengujian berikutnya mengacu pada tabel 6 Hasil Uji t - Koefisien, hasilnya terdapat permasalahan multikolinearitas pada variabel KSR, BD, BI, KSR_BD, dan KSR_BI yang dibuktikan dengan nilai VIF lebih besar dari 10 dan tolerance lebih kecil dari 0,1 . Permasalahan ini wajar terjadi karena variabel tersebut membentuk variabel moderasi yang didapatkan dari hasil perkalian KSR dengan BD dan KSR dengan BI. Dimana terdapat hubungan linier pada ketiga variabel independen tersebut untuk membentuk variabel baru yang disimbolkan dengan KSR_BD dan KSR_BI. Terakhir, Uji Heteroskedastisitas yang menggunakan scatterplot. Berdasarkan gambar 2 diperoleh titik plot yang menyebar diatas dan bawah garis horizontal 0 serta tidak ada pola yang terbentuk (Ghozali, 2018). Maka tidak adanya permasalahan heteroskedastisitas. 
Tabel 3. Hasil Uji Statistik Normalitas

\begin{tabular}{llc}
\hline & & Unstandardized Residual \\
\hline $\mathrm{N}$ & & 132 \\
Normal Parameters & Mean & 0.0000 \\
& Std.Deviation & 0.2728 \\
Most Extreme & Absolute & 0.202 \\
Differences & Positive & 0.202 \\
& Negative & -0.105 \\
Test Statistic & & 0.202 \\
Asymp.Sig.(2-tailed) & 0.000 \\
\hline
\end{tabular}

Sumber: Data Penelitian, 2021.

Sumber: Data Penelitian, 2021

Gambar 2. Hasil Uji Heteroskedastisitas

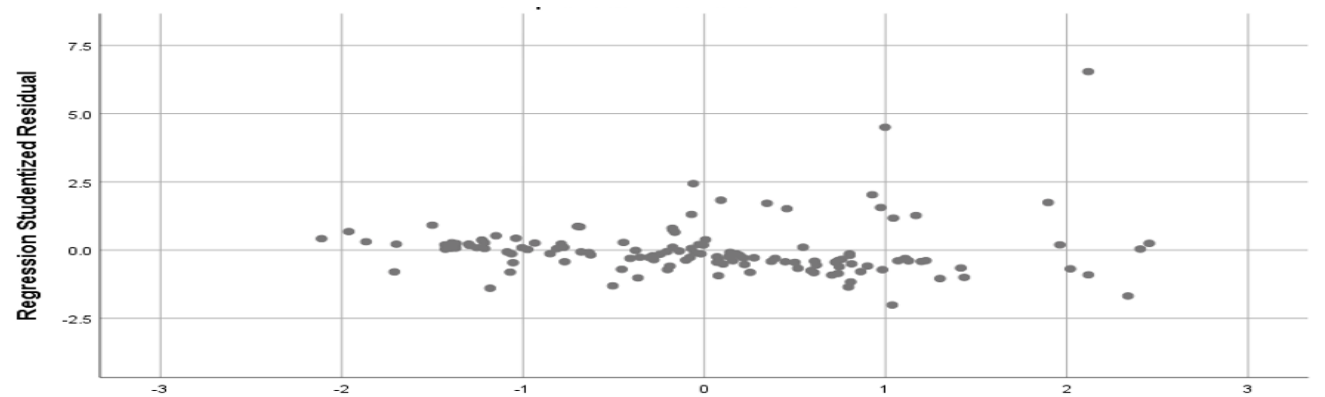

Tahapan berikutnya ialah peneliti melakukan pengujian terhadap keberartian model dengan menggunakan uji F. Dalam menguji keberartian model, peneliti mengacu pada koefisien determinasi $\left(R^{2}\right)$ pada Tabel 4. Ringkasan Model dan nilai signifikan pada Tabel 5. Hasil Uji F - Anova.

Tabel 4. Hasil Ringkasan Model

\begin{tabular}{lcccc}
\hline Model & $R$ & $R^{2}$ & Adj. $R$ Square & Std. Error of the Est. \\
\hline 1 & 0,304 & 0,092 & 0,041 & 0,280 \\
\hline
\end{tabular}

Sumber: Data Penelitian, 2021

Berdasarkan Tabel 4, hasil $\mathrm{R}^{2}$ menunjukan hasil 0,092 atau 9,2\%, artinya, variabel-variabel independen yang dipilih (NP, KSR_BI, BD, Size, BI, KSR_BD, KSR) dapat mewakili faktor-faktor yang mempengaruhi reaksi investor (CAR) sebesar $9,2 \%$. Sedangkan, sisanya sebanyak $90,8 \%$ adalah variabel yang dapat mempengaruhi reaksi investor akan tetapi tidak dipilih atau digunakan dalam penelitian ini. Tabel 5, hasil uji $\mathrm{F}$ digunakan sebagai dasar untuk melihat signifikansi model, nilai pada tabel tersebut menunjukan hasil signifikan sebesar 0,009 . Sehingga, dapat dikatakan secara keseluruhan model signifikan serta valid pada tingkat toleransi kesalahan sebesar $1 \%$.

Tabel 5. Hasil Uji F - Anova

\begin{tabular}{llccccc}
\hline \multicolumn{1}{l}{ Model } & & Sum of Square & $d f$ & Mean Square & $F$ & Sig. \\
\hline 1 & Regresi & 0,993 & 7 & 0,142 & 1,804 & 0,009 \\
& Residu & 9,750 & 124 & 0,079 & & \\
& Total & 10,742 & 131 & & & \\
\hline
\end{tabular}

Sumber: Data Penelitian, 2021

Rangkaian pengujian terakhir adalah uji hipotesis dengan menggunakan uji parsial t. Terdapat tiga pengujian hipotesis dalam penelitian ini. Poin-poin yang menjadi perhatian dalam uji ini adalah nilai $t$ atau $\beta$ serta nilai signifikan, adapun 
pada penelitian ini nilai tersebut dapat dilihat dalam Tabel 6. Hasil Uji t -Koefisien. Mengingat hipotesis yang diajukan melibatkan arah, maka nilai signifikan twotailed yang akan digunakan. Namun, pada tabel hasil nilai menunjukan nilai onetailed, sehingga, nilai tersebut perlu dibagi dua agar menjadi two-tailed.

Tabel 6. Hasil Uji t - Koefisien

\begin{tabular}{|c|c|c|c|c|c|c|c|c|}
\hline \multirow{2}{*}{\multicolumn{2}{|c|}{ Model }} & \multicolumn{2}{|c|}{ Unstdzd.Koef. } & \multirow{2}{*}{$\begin{array}{c}\text { Std. } \\
\text { Koef. } \\
\text { Beta }\end{array}$} & \multirow[b]{2}{*}{$t$} & \multirow[b]{2}{*}{ Sig. } & \multicolumn{2}{|c|}{ Collinearity Stat. } \\
\hline & & $\beta$ & $\begin{array}{l}\text { Std. } \\
\text { Error }\end{array}$ & & & & \multirow[t]{2}{*}{$\begin{array}{l}\text { Tole- } \\
\text { rance }\end{array}$} & \multirow[t]{2}{*}{ VIF } \\
\hline 1 & (Constant) & 2,049 & 0,653 & & 3,137 & 0,002 & & \\
\hline & KSR & $-1,816$ & 1,312 & $-0,686$ & $-1,384$ & 0,169 & 0,030 & 33,539 \\
\hline & BD & 0,153 & 0,599 & 0,070 & 0,255 & 0,779 & 0,097 & 10,328 \\
\hline & BI & $-1,173$ & 0,684 & $-0,473$ & $-1,713$ & 0,089 & 0,096 & 10,399 \\
\hline & KSR_BD & $-1,221$ & 1,977 & $-0,199$ & $-0,617$ & 0,538 & 0,070 & 14,237 \\
\hline & KSR_BI & 4,103 & 2,307 & 1,165 & 1,165 & 0,078 & 0,017 & 58,643 \\
\hline & SIZE & $-0,076$ & 0,022 & $-0,389$ & $-3,431$ & 0,001 & 0,570 & 1,756 \\
\hline & NP & $-0,002$ & 0,001 & $-0,213$ & $-1,803$ & 0,074 & 0,525 & 1,904 \\
\hline
\end{tabular}

Sumber: Data Penelitian, 2021

Hipotesis pertama dalam penelitian ini mengajukan bahwa laporan keberlanjutan memiliki pengaruh positif secara signifikan terhadap reaksi investor. Pada tabel koefisien untuk variabel KSR memiliki nilai t dan $\beta$ negatif serta nilai signifikan sebesar 0,0845 atau signifikansi berada pada tingkat $10 \%$. Dengan kata lain hasil menunjukan bahwa 0,0845 >0,05, maka hipotesis ini ditolak. Interpretasi dari hasil tersebut adalah laporan keberlanjutan tidak berpengaruh signifikan terhadap reaksi investor. Artinya, semakin banyak atau sedikit poin indeks pelaporan dari laporan keberlanjutan tidak berdampak pada reaksi investornya. Dalam hal ini jumlah poin indeks GRI Standar yang diungkapkan oleh perusahaan tidak cukup mempengaruhi pergerakan harga saham pada tanggal penerbitan laporan keberlanjutannya. Hasil dari hipotesis ini tidak selaras dengan penelitian terdahulu yang menyatakan bahwa kualitas laporan keberlanjutan dapat mempengaruhi reaksi investor dalam keputusan investasinya. Penelitian tersebut menggunakan sampel perusahaan yang tercatat dalam Dow Jones Index dan Inggris (Aureli et al., 2020) dan (Klerk et al., 2015). Kemudian, pada penelitian yang dilakukan terhadap perusahaan pada negara Jepang dan Inggris, terdapat hasil yang sama seperti Klerk (2015) untuk Inggris. Sedangkan, Jepang menghasilkan bahwa laporan keberlanjutan tidak berkontribusi dalam keputusan investasi investor atau reaksi investor (Bowerman \& Sharma, 2016). Rasionalisasi atas perbedaan hasil dengan Inggris dan Jepang, bisa disebabkan oleh perbedaan letak geografis yang mempengaruhi kultur dari para investor. Investor pada perusahaan Inggris lebih memilih dan memberikan nilai tambah bagi perusahaan yang bertanggung jaw ab pada aspek ESGEE (Aureli et al., 2020). Dimana, Jepang terletak pada benua yang sama dengan Singapura yakni Benua Asia.

Hipotesis kedua dalam penelitian ini mengajukan bahwa keberagaman gender direksi dapat memperkuat hubungan laporan keberlanjutan dan reaksi investor. Dalam hal ini akan dikatakan memperkuat apabila hasil dalam tabel koefisien yang menunjukan nilai positif $\mathrm{t}$ dan $\beta$ serta signifikan $<0,05$. Pada tabel tersebut untuk variabel KSR_BD menunjukan nilai $\mathrm{t}$ dan $\beta$ negatif serta nilai signifikan sebesar 0,269, yang mana hasil signifikan tersebut lebih besar dari 0,05. 
Maka hipotesis ini mengalami penolakan. Berdasarkan hasil yang didapatkan, keberagaman gender direksi tidak dapat memperkuat pengaruh laporan keberlanjutan terhadap reaksi investor. Hasil ini juga menggambarkan bahwa hubungan laporan keberlanjutan terhadap reaksi investor tidak terpengaruh dengan berapapun proporsi dari keberagaman gender. Interpretasi tersebut tidak sejalan dengan penelitian terdahulu yang mengatakan proporsi direksi berjenis kelamin wanita berpengaruh negatif signifikan. Diungkapkan juga bahwa tingginya proporsi wanita dalam dewan direksi mengakibatkan meningkatnya sensitivitas pelaporan keberlanjutan. Sehingga, laporan tersebut lebih andal dan memiliki kemampuan memberikan sinyal terhadap investor lebih baik (Arayssi et al., 2016) dan (Jizi, 2017). Keberadaan direksi wanita dalam jajaran dewan dapat menambah nilai dari laporan keberlanjutan. Akan tetapi, kecenderungan direksi wanita dalam pengambilan keputusan yaitu bersifat risk adverse. Sifat ini cenderung akan memilih investasi perusahaan yang rendah dengan tingkat pengembalian yang rendah juga. Yang mana, salah satu alasan investor untuk berinvestasi adalah untuk mendapatkan keuntungan semaksimal mungkin dari modalnya terhadap perusahaan itu. Hal inilah yang diduga menjadi penyebab keberadaan direksi wanita tidak signifikan terhadap reaksi investor.

Hipotesis ketiga dalam penelitian ini menyatakan independensi dewan direksi dapat memperkuat hubungan kualitas laporan keberlanjutan dengan reaksi investor. Sama halnya dengan hipotesis kedua, akan dikatakan memperkuat apabila hasil dalam tabel koefisien yang menunjukan nilai positif $t$ dan $\beta$ serta signifikan $<0,05$. Setelah dilakukan pengujian, nilai $t$ atau $\beta$ menghasilkan nominal positif dengan signifikan $0,039<0,05$. Oleh sebab itu, hipotesis ini terbukti diterima pada tingkat signifikan $5 \%$. Hasil pengujian tersebut menggambarkan bahwa semakin tinggi proporsi direksi independen maka akan semakin memperkuat pengaruh laporan keberlanjutan terhadap reaksi investor. Hipotesis ini belum terdapat penelitian terdahulu yang dapat mendukung hasilnya atau belum terdapat konstruk yang sama dengan penelitian ini. Namun, beberapa penelitian terdahulu yang cukup berkaitan dengan hipotesis ini menyatakan bahwa independensi dari dewan direksi dapat mempengaruhi kualitas laporan keberlanjutan dan keputusan investor secara terpisah. Rasionalisasi dari hasil ini didukung dengan teori keagenan dan teori pemangku kepentingan, direksi independen dalam dewan direksi akan menghindari permasalahan kepentingan dalam pengambilan keputusan, terutama bagi investor, pemimpin direksi yang independen lebih menambahkan nilai dalam proses penentuan investasinya (SpencerStuart, 2017). Selain itu, Perusahaan tidak hanya memperhatikan kepentingan pemegang saham atau investor saja akan tetapi seluruh pemangku kepentingannya. Dimana, direksi sebagai agen memiliki peran besar dalam pencapaiannya, guna memaksimalkan keuntungan investor dengan tetap memperhatikan seluruh pemangku kepentingan.

\section{SIMPULAN}

Temuan-temuan yang didapatkan peneliti berdasarkan hasil uji hipotesis ialah laporan keberlanjutan tidak berpengaruh signifikan terhadap reaksi investor, 
peran keberagaman gender direksi dalam memperkuat hubungan kualitas laporan keberlanjutan terhadap reaksi investor tidak signifikan, dan hubungan kualitas laporan keberlanjutan terhadap reaksi investor dapat diperkuat secara signifikan oleh proporsi direksi independen. Berdasarkan temuan-temuan ini, hipotesis pertama dan kedua mengalami penolakan dan hanya hipotesis ketiga yang dapat diterima. Selain ketiga temuan tersebut, diketahui juga berdasarkan sampel penelitian ini poin laporan keberlanjutan terendah ialah 34 poin, tertinggi sebanyak 156 poin, dan rata-rata senilai 64 poin dari total poin indeks sebanyak 235 poin.

Implikasi yang diharapkan dengan adanya penelitian ini, yaitu dapat menambah wawasan dan masukan dalam bidang akademik terkait dengan metode penelitian dan perhitungan variabel. Kemudian, investor mulai memperhatikan probabilitas keuntungan dan risiko dari suatu perusahaan berdasarkan aspek non-finansial. Hal ini bertujuan agar investor mendapatkan keuntungan maksimal dan bersiap atas risiko yang akan dihadapi. Terakhir, bagi perusahaan harapannya dapat menambah kepekaan perusahaan atasmanfaat dari adanya informasi non-finansial yang secara spesifik dalam penelitian ini memanfaatkan laporan keberlanjutan.

Temuan-temuan ini tidak dapat digeneralisasikan pada seluruh keadaan. Hal ini mengingat terbatasnya sampel serta penelitian hanya spesifik dilakukan pada perusahaan sektor industri dan sektor sumber daya mineral yang terdaftar pada SGX. Penelitian ini dilakukan sebagai bentuk pembuktian pada kondisi tertentu saja dengan segala keterbatasan yang ada. Adapun batasan yang dimaksud ialah sampel penelitian yang hanya mengunakan perusahaan dalam sektor industri dan sumber daya mineral dan masih terdapat beberapa metode lain untuk perhitungan variabel-variabel dalam penelitian ini. Dengan demikian, saran untuk penelitian selanjutnya agar dapat meminimalisir keterbatasan dalam penelitian ini dengan menambah sampel observasi agar temuannya lebih luas. Selain itu, harapannya pada penelitian berikutnya dapat menggunakan formula untuk menilai kualitas laporan keberlanjutan.

\section{REFERENSI}

Arayssi, M., Dah, M., \& Jizi, M. (2016). Women on boards, sustainability reporting and firm performance. Sustainability Accounting, Management and Policy Journal, 7(3), 376-401. https://doi.org/10.1108/SAMPJ-07-2015-0055

Aureli, S., Gigli, S., Medei, R., \& Supino, E. (2020). The value relevance of environmental, social, and governance disclosure: Evidence from Dow Jones Sustainability World Index listed companies. Corporate Social Responsibility and Environmental Management, 27(1), 43-52. https:// doi.org/10.1002/csr.1772

Benninga, S., \& Voetmann, T. (2014). Financial Modelling. In THe MIT Press (forth Edit). Massachusetts Institute of Technology.

Berk, J., DeMarzo, P., \& Harford, J. (2015). Fundamentals of Corporate Finance. In Fundamentals of Corporate Finance (Third Edit). Pearson Education.

Bernow, S., Godsall, J., Klempner, B., \& Merten., C. (2019). More than values: The value-based sustainability reporting that investors want. McKinsey $\mathcal{E}$ Company.

Bodie, Z., Kane, A., \& Marcus, A. J. (2018). Investments (Eleventh E). Mc Graw Hill Education. 
Bowerman, S., \& Sharma, U. (2016). The effect of corporate social responsibility disclosures on share prices in japan and the uk.

Brockett, A., \& Rezaee, Z. (2012). Corporate Sustainability Integrating Performance and Reporting. John Wiley \& Sons, Inc.

Bynner, J. (2015). Longitudinal Cohort Designs: Cross Sectional Data. Encyclopedia of Social Measurement.

Ching, H. Y., \& Gerab, F. (2017). Sustainability reports in Brazil through the lens of signaling, legitimacy and stakeholder theories. Social Responsibility Journal, 13(1), 95-110. https: / / doi.org/10.1108/SRJ-10-2015-0147

Deegan, C. (2002). Introduction: The legitimising effect of social and environmental disclosures - a theoretical foundation. Accounting, Auditing \& Accountability Journal, 15(3), 282-311.

Epstein, M. J., \& Buhovac, A. R. (2014). Making Sustainability Work: Best Practices in Managing and Measuring Corporate Social, Environmental, and Economic Impacts (Second Edi). Berrett-Koehler.

Event Study. (2020). Event Study Tools.

Ghozali, I. (2018). Aplikasi Analisis Multivariete dengan Program IBM SPSS 25 (9th ed.). Universitas Diponegoro.

Gray, R., Kouhy, R., Lavers, S., Gray, R., Kouhy, R., \& Lavers, S. (1995). A review of the literature and a longitudinal study of UK disclosure. Accounting, Auditing $\mathcal{E}$ Accountability Journal, 8(2), 47-125.

GSSB. (2016). Standar Pelaporan Keberlanjutan GRI 2016 : 101 Landasan. In GRI Standards.

Hasanah, H., \& Rudyanto, A. (2020). Determinan Pengungkapan Corporate Social Responsibility Perusahaan di Bursa Efek Indonesia. Equity.

Jizi, M. (2017). The Influence of Board Composition on Sustainable Development Disclosure. Business Strategy and the Environment, 26(5), 640-655.

Kaplan. (2019). Agency theory Key concepts of agency theory. Kaplan Financial Knowledge Bank.

Karim, S., Manab, N. A., \& Ismail, R. B. (2020). The dynamic impact of board composition on CSR practices and their mutual effect on organizational returns.

Klerk, M. De, Villiers, C. de, \& Staden, C. van. (2015). The influence of corporate social responsibility disclosure on share prices Evidence from the United Kingdom. Pacific Accounting Review, 27(2), 208-228.

Mulyono. (2019). Analisis Uji Asumsi Klasik.

Nazir, M. (2013). Metodologi Penelitian. In Studi kepustakaan. Ghalia Indonesia.

$\mathrm{Ng}$, A. C., \& Rezaee, Z. (2020). Business sustainability factors and stock price informativeness. Journal of Corporate Finance, 64, 101688.

Noronha, C., Guan, J., \& Fan, J. (2018). Firm value and social contribution with the interaction of corporate governance: Social contribution value per share. Sustainability Accounting, Management and Policy Journal, 9(2), 165-200.

Novita, M., \& Saputra, B. W. (2020). Pengungkapan Laporan Keberlanjutan, Perbedaan Gender dan Nilai Perusahaan.

Nyatichi, V. (2017). Moderating Influence of Board Diversity and Directors Compensation on Corporate GovernanceStructure and Financial Performance of the companies listed on the Nairobi Stock Exchange. International Journal of Accounting Research, 05(01), 1-13. https:/ /doi.org/10.4172/2472-114x.1000136 
OJK. (2019). Penyebab Naik Turun Harga Saham Suatu Perusahaan. Otoritas Jasa Keuangan.

Parmar, B. L., Freeman, R. E., Harrison, J. S., Wicks, A. C., Purnell, L., \& de Colle, S. (2010). Stakeholder theory: The state of the art. Academy of Management Annals.

Patten, D. M. (1992). Intra-industry environmental disclosures in response to the Alaskan oil spill: A note on legitimacy theory. Accounting, Organizations and Society, 17(5), 471-475. https:// doi.org/10.1016/0361-3682(92)90042-Q

Rezaee, Z. (2009). Corporate Governance and Ethics. John Wiley \& Sons, Inc.

Rezaee, Z., Tsui, J., Cheng, P., \& Zhou, G. (2019). Business sustainability in Asia: Compliance, performance, and integrated reporting and assurance. In Business Sustainability in Asia: Compliance, Performance, and Integrated Reporting and Assurance. https:/ / doi.org/10.1002/9781119502302

Sekaran, U., \& Bougie, R. (2016). Research Methods for Business (Seventh Ed). John Wiley \& Sons Ltd. https:/ /doi.org/10.1007/978-94-007-0753-5_102084

Setiawan, A. (2015). Pengaruh Intelectual Capital terhadap ROA Perusahaan. 43-56.

SGX. (2016). Practice Note 7 . 6 Sustainability Reporting Guide. In Singapore Exchange Rulebooks.

SGX. (2017). An Investor's Guide to The Minerals Industry. SGX The Asian Gateway. SpencerStuart. (2017). Board Composition and Performance: What Shareholders Want to Know.

Tan, A., Benni, D., \& Liani, W. (2016). Determinant of Corporate Social Responsibility Disclosure. Journal of Auditing, Finance, and Forensic Accounting, 6(S4), 11-17. https:// doi.org/10.21107/jaffa.v7i1.6184

Tate, W. L., Ellram, L. M., \& Kirchoff, J. F. (2010). Corporate social responsibility reports: A thematic analysis related to supply chain management.

Thorne, L., Mahoney, L. S., \& Manetti, G. (2014). Motivations for issuing standalone CSR reports: A survey of Canadian firms. 